\title{
Is There an Association Between Extreme Levels of Boron Exposure and Decrease in Y:X Sperm Ratio in Men? Results of an Epidemiological Study
}

\author{
Erkeklerde Y:X Sperm Oranındaki Azalma ile Aşırı Düzeyde Bor Maruziyeti \\ Arasında Bir İlişki Var mıdır? Epidemiyolojik Çalışma Sonuçları
}

\author{
(D) Can Özgür YALÇIN, (D) Aylin ÜSTÜNDAĞ, (D) Yalçın DUYDU* \\ Ankara University, Faculty of Pharmacy, Department of Toxicology, Ankara, Turkey
}

\begin{abstract}
Objectives: A negative association between Y:X sperm ratio and high levels of boron exposure was suggested in an epidemiological study conducted in boron mining areas of China. That study, however, was criticized by many authors due to some weaknesses in the study design. The present epidemiological study was designed to corroborate or refute the above-mentioned negative association between boron exposure and $\mathrm{Y}$ :X sperm ratio in men.

Materials and Methods: The study was conducted in a boric acid production zone in Bandırma. One hundred sixty-three male workers voluntarily participated in our study. The workers employed in the boric acid production facilities were assigned as the exposed workers ( $n=86$ ). The control group was composed of workers employed in the steam power plant, energy supply unit, demineralized water plant, mechanical workshop, etc. $(n=77)$. Blood and semen samples were sampled from the participating workers at the end of the work shift. Y:X sperm ratio in semen samples was determined by fluorescence in situ hybridization. Boron concentrations in semen and blood samples were determined using inductively coupled plasma-mass spectrometry.

Results: Boron-mediated adverse effect on the $Y: X$ sperm ratio was not determined in workers in our study even under extreme occupational exposure conditions. The results of our study refute the negative association between Y:X sperm ratio and high levels of boron exposure that was suggested in a previously published epidemiological study conducted in boron mining areas of China.

Conclusion: The results of our study indicate that boron-mediated adverse effects on the $\mathrm{Y}: \mathrm{X}$ sperm ratio do not seem possible even under occupational boron exposure conditions.
\end{abstract}

Key words: Boron exposure, blood boron concentration, semen boron concentration, FISH, Y:X sperm ratio

öz

Amaç: Çin'in bor madenciliği yapılan bölgesinde yürütülmüş olan bir epidemiyolojik çalışma sonucunda, erkeklerin $Y: X$ sperm oranı ile yüksek seviyedeki bor maruziyeti arasında negatif bir ilișki olduğu belirtilmiştir. Ancak bu çalıșma, çalışmanın tasarımındaki bazı zayıflıklar nedeni ile pek çok bilim insanı tarafından eleştirilmiştir. Bu çalışma, yukarıda söz edilmiş olan erkeklerin Y:X sperm oranı ile yüksek seviyedeki bor maruziyeti arasında negatif bir ilişki olduğu iddiasını doğrulamak ya da çürütmek amacıyla yapılmıştır.

Gereç ve Yöntemler: Bu çalıșma Bandırma borik asit üretimi yapılan bölgede gerçekleștirilmiștir. Bu çalıșmaya 163 erkek ișçi gönüllü olarak katılmıştır. Borik asit üretim tesislerinde istihdam etmekte olan ișçiler maruziyet grubu olarak tanımlanmışlardır ( $n=86$ ). Kontrol grubu ise, buhar santrali, enerji tedarik ünitesi, demineralize su ünitesi, mekanik atölye gibi iş kollarında çalışan işçilerden oluşturulmuştur ( $n=77$ ). Vardiya sonlarında çalışmaya katılan işçilerden kan ve meni örnekleri alınmıştır. Erkeklerdeki Y:X sperm oranları floresan in situ hibridizasyon tekniği ile tespit edilmiştir. Kan ve meni örneklerindeki bor konsantrasyonları indüktif eşleşmiş plazma-kütle spektrometresi ile tayin edilmiştir.

Bulgular: Olağanüstü mesleki maruziyet koşulları altında bile bor maruziyetine bağlı olarak işçilerde $\mathrm{Y}: \mathrm{X}$ sperm oranlarında olumsuz bir etki gözlenmemiștir. Bizim çalışmamızın sonuçları, Y:X sperm oranı ile yüksek seviyedeki bor maruziyeti arasındaki negatif ilișkiyi reddetmektedir.

Sonuç: Bizim çalışmamızdan elde etmiş olduğumuz sonuçlar, ağır mesleki bor maruziyeti koşulları altında bile bor maruziyetinin erkeklerde Y:X sperm oranları üzerinde olumsuz bir etkisinin olmadığını göstermektedir.

Anahtar kelimeler: Bor maruziyeti, kan bor konsantrasyonu, meni bor konsantrasyonu, FISH, Y:X sperm oranı

*Correspondence: E-mail: duydu@pharmacy.ankara.edu.tr, Phone: +90 3122033118 ORCID-ID: orcid.org/0000-0001-7482-086X

Received: 02.06.2018, Accepted: 26.06.2018

๑Turk J Pharm Sci, Published by Galenos Publishing House. 


\section{INTRODUCTION}

Boric acid and borates are classified as toxic to reproduction under "Category 1B" with the hazard statement of "H369 FD" in the European Regulation on Classification, Labelling and Packaging of Substances and Mixtures.' The scientific background of this classification is based on the results of animal experiments (hazard assessment). In fact, the boron concentrations tested in animal experiments were too high and from this point of view these dose levels were not relevant to humans. Nevertheless, this classification triggered epidemiological studies in areas of high boron exposure in order to assess the risk of the daily boron exposure levels in those areas. The first study was conducted in mining areas located in Kuandian City, China. ${ }^{2}$ The blood boron concentration reported in that study was $499.2 \pm 790.6(20.4-3568.9) \mathrm{ppb}$. In spite of this extreme level of boron exposure the reproductive toxicity biomarkers reported in that study did not indicate adverse effects on male reproduction. The second comprehensive epidemiological study was conducted by our study group in workers employed in Bandırma boric acid production plant. The mean blood boron concentration of the high exposure group in our study was $223.89 \pm 69.49(152.82-454.02) \mathrm{ng} / \mathrm{g}$ and no boron-mediated unfavorable effects on reproductive toxicity parameters of male workers were observed., The results of our study were in agreement with those of the study conducted in China. Accordingly, both studies clearly indicate that boronmediated adverse effects on male reproduction do not seem possible even under extreme occupational exposure conditions. However, in 2008 Robbins et al. ${ }^{5}$ reported a boron-mediated decrease in $Y: X$ sperm ratio in workers residing in mining areas of Kuandian City. Essentially, a boron-mediated decrease in $Y: X$ sperm ratio was not observed in earlier epidemiological studies or even in animal experiments. Therefore, the results of the study published by Robbins et al. ${ }^{5}$ had to be verified by an epidemiological study. The major aim of the present epidemiological study was to corroborate or refute the negative association between the high level of boron exposure and the decrease in the $Y: X$ sperm ratio in men suggested by Robbins et al. ${ }^{5}$

\section{MATERIALS AND METHODS}

The blood and semen samples were sampled in accordance with the study protocols approved by the Ethics Committee of Hacettepe University School of Medicine (HEK 08/167, date: 22/10/2008). All participants gave their informed consent prior to participation in the project.

\section{Sampling procedure}

The present study was performed using the blood and semen samples obtained within the scope of our "Boron Project - I", which was completed in 2010.3.4 The "Boron Project - I" was conducted in Bandırma boric acid production zone and 204 workers were enrolled in that study. After the project was completed, the remaining semen samples were stored under appropriate conditions (cryopreserved in liquid nitrogen). The total number of remaining semen samples was 163 and 86 of them were from workers employed in the boric acid production facilities and were assigned as the samples of the exposed group of workers. The rest of the semen samples, from workers employed in the steam power plant, energy supply unit, demineralized water plant, mechanical workshop etc., were assigned as the control samples $(n=77)$. The demographic information, blood boron concentrations, semen boron concentrations, and sperm concentrations of these 163 workers had been gathered within the scope of the "Boron Project - I". More detailed information about the samples and the sampling area were provided in our previously published studies. ${ }^{3.4}$

\section{Boron analysis}

Blood and semen samples were analyzed by inductively coupled plasma mass spectrometry with a flow injection system. A special sample introduction system that included a perfluoroalkoxy spray chamber and a nebulizer with an alumina injector tube in a quartz torch was used for this study. The details of the above-mentioned analyses were published in our previous study. ${ }^{3}$

\section{Sperm analysis}

The semen samples were sampled and analyzed in accordance with the recommendations of the World Health Organization. ${ }^{6}$ Sperm concentrations were determined in fresh semen samples using an SQA-V Gold Sperm Quality Analyzer. The results were expressed as $10^{6}$ sperm cells $/ \mathrm{mL}$.

\section{Determination of $Y: X$ sperm ratios}

$\mathrm{Y}$ - or $\mathrm{X}$-bearing sperm cells in semen samples were detected using fluorescence in situ hybridization (FISH). The Cytocell FAST FISH prenatal $\mathrm{X}, \mathrm{Y}$, and 18 Enumeration Probe Kit (LPF 002) was used in the detection and quantification of chromosomes $\mathrm{X}, \mathrm{Y}$, and 18 by FISH. The probes are specific for the alpha satellite DNA sequences in the DXZ1, DYZ3, and D18Z1 regions of chromosomes $X$ (green), $Y$ (orange), and 18 (blue), respectively.

The semen samples were removed from the liquid nitrogen, thawed at room temperature in PBS solution, and centrifuged in an appropriate centrifuge tube at $500 \times \mathrm{g}$ for $5 \mathrm{~min}$ as the initial step of the procedure. The supernatant was gently discarded and the precipitated sperm cells were used in sperm FISH analysis. The cells were resuspended in $10 \mathrm{~mL}$ of $0.075 \mathrm{M} \mathrm{KCl}$ and left at $37^{\circ} \mathrm{C}$ for $1 \mathrm{~h}$. After centrifugation for $5 \mathrm{~min}$ at $1000 \mathrm{rpm}$ the supernatant was discarded and the precipitated sperm cells were resuspended in $5 \mathrm{~mL}$ of $\left(4^{\circ} \mathrm{C}\right)$ Carnoy's solution. The cell suspension was centrifuged again for $5 \mathrm{~min}$ at $1000 \mathrm{rpm}$. This process was repeated 3 times. Afterwards, a sufficient amount of these sperm cells was transferred directly onto the slide and allowed to dry at room temperature. The slides then were washed in $2 \times$ saline-sodium citrate (SSC) ( $3 \mathrm{~min}$ ), $70 \%$ ethanol ( $3 \mathrm{~min}$ ), $85 \%$ ethanol ( $3 \mathrm{~min}$ ), and finally in $100 \%$ ethanol ( $3 \mathrm{~min}$ ). The slides and the probe were prewarmed on a $37^{\circ} \mathrm{C}$ hotplate for 10 min. A sufficient amount of probe mixture $(10 \mu \mathrm{L})$ was pipetted onto the sperm cells and coverslipped. The slides were placed on a hotplate at $75^{\circ} \mathrm{C}$ for $5 \mathrm{~min}$ for denaturation. Afterwards the slides were transferred into a humid and dark (lightproof) 
incubator at $37^{\circ} \mathrm{C}$ for $\sim 18 \mathrm{~h}$ (overnight) for hybridization. After the waiting period, the coverslips were removed and the slides were immersed into $0.4 \times \mathrm{SSC}$ at $67^{\circ} \mathrm{C}$ for $30 \mathrm{~s}$. The washing process continued with $2 \times$ SSC + Tween-20 (room temperature) again for $30 \mathrm{~s}$. The slides were left to drain. Next, $15 \mu \mathrm{L}$ of DAPI antifade was applied onto each hybridization area, which was then covered with a coverslip. The slides were left in the dark for 15 min to allow color development. Afterwards the slides were viewed under a fluorescence microscope. The sperm cells were analyzed via fluorescence microscopy using a Leica DM1000 microscope with DAPI, AQUA, G/R filters. Leica provided a suitable set-up for simultaneous visualization of DAPI and the triple fluorochromes (spectrum green, orange, and aqua). A total of 5000 morphologically preserved sperm cells were counted per sample by one experienced scorer. The microscopic images of some sperm cells are shown in Figure 1.

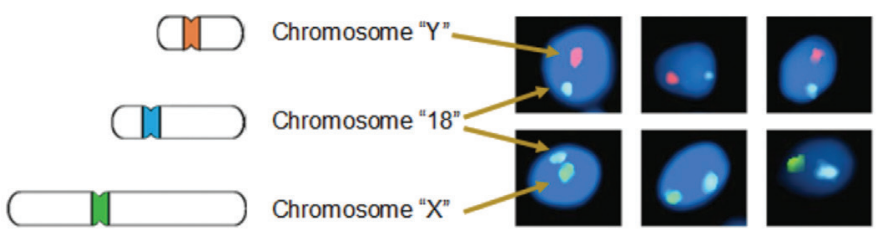

Figure 1. Left illustrations: Probe specifications: "X" centromere, Xp11.1-q11.1 (DXZ1) green; "Y" centromere, Yp11.1-q11.1 (DYZ3) orange; "18" centromere, 18p11.1-q11.1 (D18Z1) blue. Right illustrations: Microscopic sperm images after applying fluorescence in situ hybridization. The existence of green and blue dots in sperm cells means that the sperm cell contains chromosomes $X$ and 18 (internal standard). The existence of orange and blue dots in sperm cells means that the sperm cell contains chromosomes $Y$ and 18 (internal standard)

\section{Statistical analysis}

The Kruskal-Wallis and Wilcoxon Mann-Whitney $U$ tests were used to analyze some of the variables in Table 1. The statistical significance between the number of girls and boys (at birth) was analyzed using the $\chi^{2}$ test. Box plots (Figure 2), Pearson's correlation coefficient, and linear regression (Figure 3) show the empirical distribution and possible linear dependencies.

All statistical tests were performed with IBM SPSS Statistics Version 23. The significance levels of the tests were set at 0.05 .

\section{RESULTS}

The study population was composed of control $(n=77)$ and exposed $(n=86)$ groups of workers employed in Bandırma boric acid production zone. The "ages" and "years of employment" of the workers did not differ significantly between the control and exposed groups as shown in Table 1. The participating workers were healthy and were not taking any medication during the sampling period.

The mean blood boron concentration of the exposed group (141.55 ng B/g blood) was significantly higher ( $p<0.05)$ than that of the control group (63.56 ng B/g blood) (Table 1, Figure 2). This significant difference between the control and exposed groups supports the high level of daily boron exposure for the workers assigned to the exposed group. This finding was also
Table 1. Characteristics of male workers assigned to the control and exposed groups

\begin{tabular}{|c|c|c|c|}
\hline Parameters & $\begin{array}{l}\text { Control group, } \\
\mathrm{n}=77\end{array}$ & $\begin{array}{l}\text { Exposed group, } \\
\mathrm{n}=86\end{array}$ & $p$ value \\
\hline Age & $\begin{array}{l}42.86 \pm 5.06 \\
(33-48) \\
\end{array}$ & $\begin{array}{l}42.45 \pm 4.61(33- \\
48)\end{array}$ & $p>0.05$ \\
\hline $\begin{array}{l}\text { Years of } \\
\text { employment }\end{array}$ & $\begin{array}{l}18.02 \pm 6.58 \\
(2-23)\end{array}$ & $\begin{array}{l}15.76 \pm 7.16(1.62- \\
22)\end{array}$ & $p>0.05$ \\
\hline $\begin{array}{l}\text { Sperm } \\
\text { concentration } \\
\left(\times 10^{6} / \mathrm{mL}\right)\end{array}$ & $\begin{array}{l}68.08 \pm 41.37 \\
(9.69-139.21)\end{array}$ & $\begin{array}{l}64.96 \pm 56.09 \\
(11.06-161.98)\end{array}$ & $p>0.05$ \\
\hline $\begin{array}{l}\text { Blood boron conc., } \\
\text { ng B/g blood }\end{array}$ & $\begin{array}{l}63.56 \pm 43.89 \\
(21.45-134.57)\end{array}$ & $\begin{array}{l}141.55 \pm 80.43 \\
(41.28-286.30)\end{array}$ & $p<0.05$ \\
\hline $\begin{array}{l}\text { Semen boron } \\
\text { conc., } \\
\text { ng B/g semen }\end{array}$ & $\begin{array}{l}1127.78 \pm 1713.96 \\
(66.4-5115.6)\end{array}$ & $\begin{array}{l}1703.42 \pm 1895.09 \\
(452.60-7067.85)\end{array}$ & $p<0.05$ \\
\hline $\mathrm{Y}: \mathrm{X}$ sperm ratio & $\begin{array}{l}0.99 \pm 0.03 \\
(0.94-1.01) \\
\end{array}$ & $\begin{array}{l}0.99 \pm 0.02(0.96- \\
1.01)\end{array}$ & $p>0.05$ \\
\hline Fathered children & $136(1.77)^{\star}$ & $150(1.74)^{*}$ & $p>0.05$ \\
\hline Girls (at birth) & $70(0.91)^{\star}$ & $69(0.80)^{*}$ & $p>0.05$ \\
\hline Boys (at birth) & $66(0.86)^{\star}$ & $81(0.94)^{*}$ & $p>0.05$ \\
\hline Girls \% (at birth) & 51.47 & 46.00 & $p>0.05$ \\
\hline
\end{tabular}

The results are given as mean \pm standard deviation $\left(5^{\text {th }}-95^{\text {th }}\right)$, * $m e a n$ values
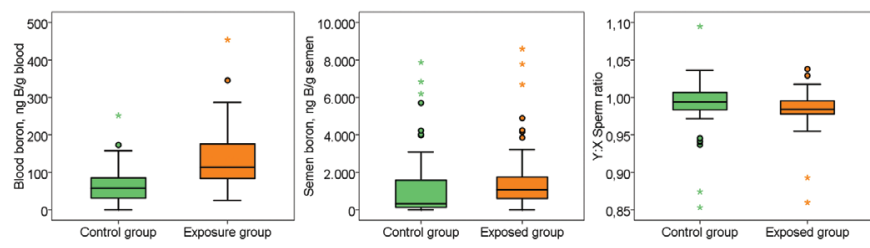

Figure 2. Box-plot graphs of boron concentrations in blood and semen samples of the control and exposed groups are shown in the first two charts. The distribution of $\mathrm{Y}: \mathrm{X}$ sperm ratio in the control and exposed groups is shown in the rightmost chart
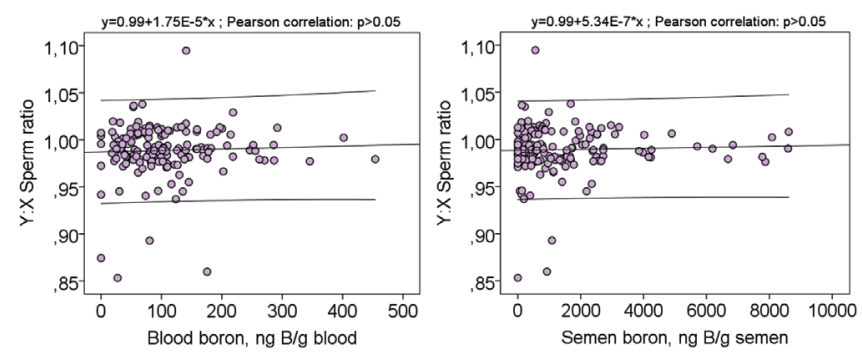

Figure 3. Linear regressions and correlations between blood/semen boron concentrations and $\mathrm{Y}: \mathrm{X}$ sperm ratios

supported by the semen boron concentrations of workers. The mean semen boron concentrations of the control and exposed groups were significantly different $(p<0.05)$ from each other and thereby provided additional support for the extraordinary daily boron exposure conditions in our study population (Table 1).

The high level of boron exposure in the exposed group of workers did not adversely affect the sperm concentrations 
or $\mathrm{Y}: \mathrm{X}$ sperm ratios of workers as shown in Table 1 and Figure 2. This finding is also supported by the lack of statistically significant correlation (Pearson, $p>0.05$ ) between blood/semen boron concentrations and $\mathrm{Y}: \mathrm{X}$ sperm ratios in workers (Figure 3 ).

Boron-mediated effects on the sex ratio at birth were also investigated within the scope of this study. However, no shift in the sex ratio at birth toward females was observed. As shown in Table 1, the percentage of girls at birth in the exposed group was not significantly higher than that in the control group ( $p>0.05)$.

\section{DISCUSSION}

Some earlier studies performed on the relation between boron exposure and sex ratio at birth reported an excess of female offspring in highly boron exposed populations. In spite of an increase in female offspring, the increase was not statistically significant in these previously published studies. ${ }^{7-9}$ In 2008, however, Robbins et al. ${ }^{5}$ reported a statistically significant relation between boron exposure and $Y: X$ sperm ratio in male workers employed in a boron mining company in Kuandian City, China. The authors reported a significant association between a high level of boron exposure and a decrease in $Y$-bearing versus $X$-bearing sperm cells. Moreover, the excess of female offspring around the boron mining area in Kuandian City (China) was attributed to the decrease in the $Y: X$ sperm ratios in highly boron exposed men. ${ }^{5}$ Although the results of that study were criticized by some authors due to weaknesses in the study design, a study confirming or rejecting the results of this study has not been performed thus far. ${ }^{10}$ Therefore, the major aim of the present study was to corroborate or refute the results reported by Robbins et al. ${ }^{5}$

The Bandırma boric acid production zone is a suitable place for investigating boron-mediated unfavorable effects on the $Y: X$ sperm ratios in men. This study area provided a wide range of daily boron exposure, which made it possible to study dosedependent responses of the studied parameters.

The high level of daily boron exposure in our study area was supported by using boron exposure biomarkers. Blood boron and to a lesser extent semen boron concentrations were suggested as biomarkers of boron exposure in some earlier studies. 3,4,1-16 Accordingly, blood boron and semen boron concentrations were used as the biomarkers of boron exposure in order to prove the high level of daily boron exposure of workers classified in the exposed group. The significantly high mean blood boron and semen boron concentrations in the exposed group support the extraordinary daily boron exposure level in our study population as shown in Table 1.

In spite of this high level of daily boron exposure, the mean $Y: X$ sperm ratio of the exposed group was not significantly different from that of the control group ( $p>0.05$ ) as shown in Table 1. The sex ratio (boys/girls) at birth in the control and exposed groups was 0.94 and 1.17, respectively. In this regard, the numbers of boys and girls in the control and exposed groups were not significantly different ( $p>0.05$ ) as presented in Table 1.

\section{CONCLUSIONS}

Consequently, boron-mediated decrease in $\mathrm{Y}: \mathrm{X}$ sperm ratios in men or excess of female births were not observed in our highly boron-exposed study population. Under these circumstances, our results refute the association between a high level of boron exposure and decreased $\mathrm{Y}: \mathrm{X}$ sperm ratios in men that was reported by Robbins et al. ${ }^{5}$

\section{ACKNOWLEDGEMENTS}

The study was funded by Eti Mine Works General Management and BOREN (2008-G0207).

Conflicts of Interest: No conflict of interest was declared by the authors.

\section{REFERENCES}

1. Regulation (EC) No $1272 / 2008$ on the classification, labelling and packaging of substances and mixtures. 16 December 2008.

2. Xing X, Wu G, Wei F, Liu P, Wei H, Whang C, Xu J, Xun L, Jia J, Kennedy $N$, Elashoff D, Robbins W. Biomarkers of environmental and workplace boron exposure. J Occup Environ Hyg. 2008;5:141-147.

3. Duydu $Y$, Başaran N, Üstündağ $A$, Aydin $S$, Ündeğer Ü, Ataman OY, Aydos K, Düker Y, Ickstadt K, Waltrup BS, Golka K, Bolt HM. Reproductive toxicity parameters and biological monitoring in occupationally and environmentally boron-exposed persons in Bandırma, Turkey. Arch Toxicol. 2011;85:589-600

4. Duydu Y, Başaran N, Ustündağ A, Aydin S, Undeğer U, Ataman OY, Aydos K, Düker Y, Ickstadt K, Waltrup BS, Golka K, Bolt HM. Assessment of DNA integrity (COMET assay) in sperm cells of boron-exposed workers. Arch Toxicol. 2012;86:27-35.

5. Robbins WA, Wei F, Elashoff DA, Wu G, Xun L, Jia J. Y:X sperm ratio in boron exposed men. J Androl. 2008;29:115-121.

6. World Health Organization. WHO laboratory manual for the examination and processing of human semen. Fifth Edition; 2010.

7. Whorton D, Haas J, Trent L. Reproductive effects of inorganic borates on male employees: birth rate assessment. Environ Health Perspect. 1994;102(Suppl 7):129-132.

8. Chang BL, Robbins WA, Wei F, Xun L, Wu G, Li N, Elashoff DA. Boron workers in China, exploring work and lifestyle factors related to boron exposure. AAOHN J. 2006;54:435-443.

9. Sayli BS. An assessment of fertility in boron-exposed Turkish subpopulations, 2. Evidence that boron has no effect on human reproduction. Biol Trace Elem Res. 1998;66:409-422.

10. Scialli AR, Bonde JP, Brüske-Hohlfeld I, Culver BD, Li Y, Sullivan FM. An overview of male reproductive studies of boron with an amphasis on studies of highly exposed Chinese workers. Reprod Toxicol. 2010;29:10-24.

11. Duydu Y, Basaran N, Bolt HM. Risk Assessment of Borates in Occupational Settings ( (1t $^{\text {eds. }) ~ E l s e v i e r ; ~ 2015: 65-105 . ~}$

12. Duydu Y, Basaran N, Bolt HM. Exposure assessment of boron in Bandırma boric acid production plant. J Trace Elem Med Biol. 2012;26:161-164.

13. Duydu Y, Basaran N, Ustündağ A, Aydın S, Undeğer U, Ataman OY, Aydos K, Düker Y, Ickstadt K, Waltrup BS, Golka K, Bolt HM. Is boric acid toxic to 
reproduction in humans? Assessment of the animal reproductive toxicity data and epidemiological study results. Curr Drug Deliv. 2016;13:324329.

14. Basaran N, Duydu Y, Bolt HM. Reproductive toxicity in boron exposed workers in Bandirma, Turkey. J Trace Elem Med Biol. 2012;26:165-167.
15. Bolt HM, Duydu Y, Basaran N, Golka K. Boron and its compounds: current biological research activities. Arch Toxicol. 2017;91:2719-2722.

16. Bolt HM, Basaran N, Duydu Y. Human environmental and occupational exposures to boric acid: reconciliation with experimental reproductive toxicity data. J Toxicol Environ Health A. 2012;75:508-514. 